\title{
EARLY DETECTION OF SPONTANEOUS COMBUSTION DISASTER OF SULPHIDE ORE STOCKPILES
}

\author{
Hui Liu, Zhixing Wang, Jian Zhong, Zhengwen Xie
}

Original scientific paper The fire hazards induced by the spontaneous combustion of sulphide ores pose safety, environmental, and economic concerns to the mining and metallurgical industries and have become one of the most important problems in mining, particularly when sulphide ores have to be stored for a long time or transported for a long distance. The first purpose of this paper is the selection of a suitable detection indicator for running through the entire process of spontaneous combustion from oxidation to fire and accurately determining the position of the fire source of the spontaneous combustion of sulphide ore stockpiles at an early stage. We conducted on-site and laboratory experiments by using five indices to assess the oxidation characteristics of sulphide ores. Experimental results show that the change of surface temperature on sulphide ore stockpiles could indirectly reflect the nature of sulphide ore oxidation and is closely related to the various stages of spontaneous combustion. On the basis of the temperature anomaly analyses and infrared thermal imaging technology, a new fire source detection method, which can monitor the highest temperature point on the surface of self-igniting ores, was proposed. The investigation result shows that the maximum temperature differences are 0,$5 ; 0,16$ and $0,04{ }^{\circ} \mathrm{C}$ at the detection depths of 2,3 , and $5 \mathrm{~m}$, respectively, and a scope of $1 \times 1 \mathrm{~m}$ when close to the self-ignition duration. Under the same condition, the maximum temperature differences are 1,$39 ; 0,53$ and $0,14{ }^{\circ} \mathrm{C}$ at a scope of $2 \times 2 \mathrm{~m}$. Therefore, the infrared thermal imaging system with a sufficiently high accuracy can be used to measure the temperature differences on the surface of ore stockpiles, thus resulting in the determination of fire source position.

Keywords: mine safety; sulphide ore stockpiles; spontaneous combustion; detection of fire source; infrared thermal imaging

Rano otkrivanje katastrofe nastale spontanim izgaranjem naslaga sulfidne rude

Izvorni znanstveni članak Opasnost od vatre izazvane spontanim izgaranjem sulfidnih rudača važno je sigurnosno, ekološko i ekonomsko pitanje za rudarstvo i metalurgiju, a postalo je jedan od najvažnijih problema u rudarstvu, posebice kada je potrebno dugotrajno uskladištiti sulfidne rudače ili ih prenositi na velike udaljenosti. Osnovna je svrha ovoga rada odabir odgovarajućeg indikatora detekcije kroz cjelokupni proces spontanog izgaranja od oksidacije do vatre uz točno određivanje mjesta nastanka vatre kod spontanog izgaranja naslaga sulfidne rude u ranom stadiju. Proveli smo terenske i laboratorijske eksperimente koristeći pet pokazatelja kako bi odredili karakteristike oksidacije sulfidnih rudača. Eksperimentalni rezultati pokazuju da bi promjena površinske temperature na naslagama sulfidne rudače mogla indirektno odražavati prirodu oksidacije sulfidne rudače te da je usko povezana s različitim stadijima spontanog izgaranja. Na temelju analiza temperaturnih anomalija i tehnologije infracrvene termografije, predložena je nova metoda za otkrivanje izvora vatre, kojom se može pratiti najviša točka temperature na površini samozapaljivih rudača. Rezultat istraživanja pokazuje da su maksimalne razlike temperature 0,$5 ; 0,16$ i $0,04{ }^{\circ} \mathrm{C}$ na dubinama detekcije od 2,3 i $5 \mathrm{~m}$, i površine od $1 \times 1 \mathrm{~m}$ kada su blizu samozapaljenju. Pod istim uvjetima, maksimalne razlike temperature su 1,$39 ; 0,53$ i $0,14{ }^{\circ} \mathrm{C}$ površine od $2 \times 2 \mathrm{~m}$. Stoga se sustav infracrvene termografije može koristiti s dovoljno visokom točnošću za mjerenje temperaturnih razlika na površini naslaga rudača, rezultirajući određivanjem položaja mjesta nastanka vatre.

Ključne riječi: sigurnost rudnika; naslage sulfidnih rudača; spontano izgaranje; detekcija izvora vatre; infracrvena termografija

\section{Introduction}

The term "spontaneous combustion of sulfide ore stockpiles" describes the physical and chemical processes of thermal runaway, which occurs because of the accelerating exothermic reaction of the sulfide ore and oxygen in air even under ambient conditions. This process can pose a potential problem when the heat produced cannot completely dissipate to the surroundings. With the accumulation of heat produced by the increasingly rapid oxidation exothermic reaction, thermal runaway may occur, thus leading to ignition. The spontaneous combustion of sulfide ores can induce fire hazards, which are one of the most significant problems in the mining, transportation, and storage processes in relation to economics and safety. This type of spontaneous fire hazard is considered one of the most destructive natural hazards in mining and metallurgical industries. A large amount of spontaneous fire hazards in sulfide ore mines or other related sites throughout the world have been reported. According to an observation of the years $1869 \div$ 1923 (cited by Stephanie Somot (2010)) [1], approximately 10 lives are lost per year because of "metal mine fires. " In 1939, the sinking of the N. Y. K. liner S/S Boyko Maru was reported to be due to the transportation of copper [1]. The self-heating of sulfide ores in the transportation of iron-copper was first observed in 1871 (quoted by Kirshenbaum (1968)). In 1977, sulfide dust explosions and streams of molten metal in the Sullivan Mine were reported and further described by Good [2]. The self-heating and smoldering of sulfides result in air pollution in/around mines, leading to acid mine drainage [3]. Approximately $10 \%$ of iron, copper, lead, zinc, and gold mines in China contain sulfide ores with spontaneous combustion potential [4]. Several mine fire cases have been induced by the spontaneous combustion behavior of sulphide ores, such as that in Wushan Mine in Jiangxi Province and Xinqiao and Xiangshan Mines in Anhui Province. Several sulphide ore stockpiles on the ground were also confronted with the risk of spontaneous fire hazards, as shown in Fig. $1[5,6]$.

The fire disasters induced by the spontaneous combustion of sulfide ores can pose a severe threat to the mining environment because large quantities of toxic gases and intense heat are produced in the entire mine, which might lead to considerable economic loss and even loss of life.

Thus far, many researchers in different countries have exerted considerable efforts to investigating spontaneous combustion disaster of sulfide ores $[7 \div 13]$. Many previous studies have focused on the mechanisms and processes, tendency assessments, and prediction and fire 
extinguishing methods of possible spontaneous combustion of sulfide ores. Boon [7] reviewed 'direct' and 'indirect' bacterial oxidation mechanism of sulphide minerals. Yang et al. [8, 9] investigated the spontaneous combustion potential of sulfide concentrates in storage and mechanism of mechanical activation for spontaneous combustion of sulfide minerals. Dunn [10] used thermal analysis to present the oxidation of pyrite and founded the oxidation occurs as a sequence of reactions usually controlled by oxygen diffusion. Iliyas et al. [11] proposed an improved thermal analysis methodology for thermal stability and safety analysis of sulfide mineral selfheating. A quantitative method was developed by Bouffard [12] to quantify the self-heating potential of sulphide concentrates, which consisted of measuring the sulphur dioxide evolved when a concentrate was heated and oxidized in air at $300{ }^{\circ} \mathrm{C}$. Chen et al. [13] presented that Polyethylene polyamines could provide an effective protective layer for sulfide ores to reduce the penetration of atmospheric oxygen and the oxidation of these ores.

Over the past years, significant achievements have been attained in understanding the chemical, thermodynamical, and electrochemical mechanisms, as well as the geological investigations, spontaneous combustion potential tests, oxidation suppressants, ventilation, and other relevant measures. However, an understanding of the exact mechanism of spontaneous combustion is still lacking because of the existence of a variety of internal and external factors that influence the

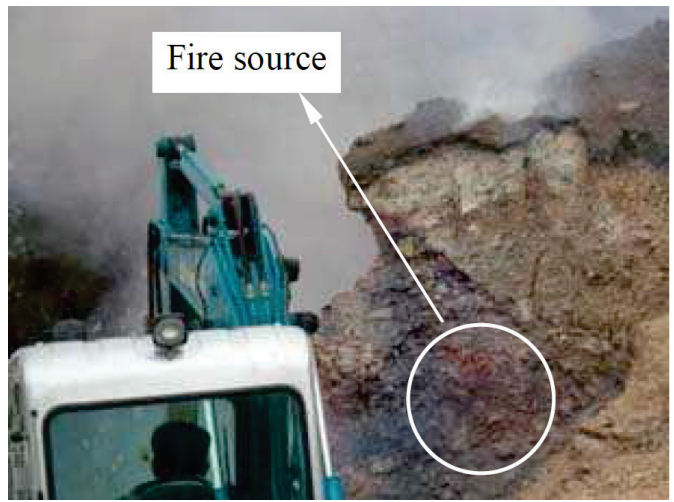

Figure 1 (a) Spontaneous combustion of millions of tons of ores at an ore field in Guizhou Province

\section{Experimental method}

\subsection{Ore sample selection}

The ore samples used for the experiments in this study should have spontaneous combustion potential. On the basis of the examination of ore spontaneous combustion tendency for a sulphide iron mine in Henan Province and the investigation of several cases of fire physical and chemical processes of spontaneous combustion. Thus, fully predicting the outbreak of spontaneous combustion is difficult. In practice, detection methods are often implemented by mine operators to assess the state of spontaneous combustion of sulfide ore stockpiles. A variety of test methods are currently in use for the detection of open fires and spontaneous combustion in mines and other fields, such as temperature or heat measurements $[15,16]$, index gases measurement methods $[17 \div 19]$, NOAA/AVHRR data [20], numerical modeling [21], radon method [22], and infrared detection methods [4, 23]. Among these methods, the index gases measurement is usually used by coalmines. The exact reaction mechanism of the process is completely different between coal and sulphide ores, even if they have the same low-temperature reaction leading to spontaneous combustion. For temperature or heat measurements, little attention has been focused on the processes causing temperature anomalies on the surface. Therefore, we need to conduct further research on the heat-releasing characteristics and oxidation product-generating patterns of the spontaneous combustion of sulfide ores such that the preferred evaluation index can be obtained to detect the onset of the spontaneous combustion of sulfide ore stockpiles at an early stage. Three large-scale sulfide ore stockpiles were piled in a stope to obtain the preferred index and achieve the early detection of spontaneous combustion.

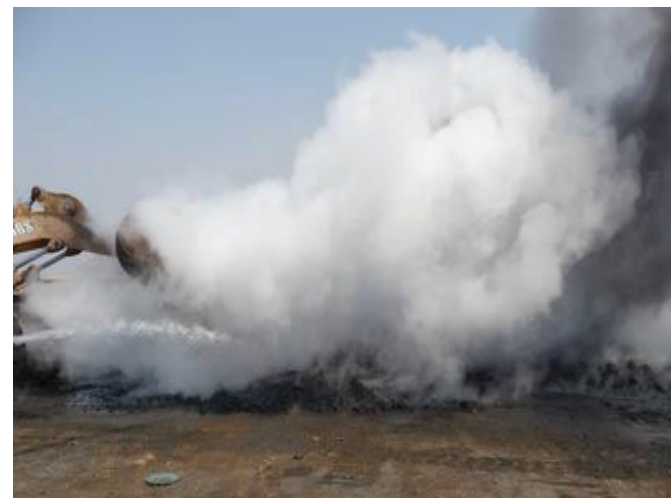

Figure 1(b) Spontaneous combustion of 30 tons of iron ore stockpiles at an outdoor yard in Hubei Province

outbreaks in the mine, the types of ore samples with typical spontaneous combustion potential in the mine were determined to be melnikovite-pyrite and pyrite of small crystal size. Ore mineral composition and structures were measured by a microscopic analysis system. The results of mineragraphy analysis of the ore samples used are shown in Fig. 2 and Tab. 1.

Table 1 Ore types and chemical composition of the ore samples used for the test

\begin{tabular}{|c|c|c|c|c|c|c|c|c|c|c|}
\hline \multirow{2}{*}{ No. } & \multirow{2}{*}{ Ore types } & \multirow{2}{*}{ Crystal size / mm } & \multirow{2}{*}{ Content / wt. $\%$} & \multicolumn{7}{|c|}{ Chemical composition and content / wt.\% (mainly) } \\
\hline & & & & $\mathrm{TFe}$ & $\mathrm{Fe}^{2+}$ & TS & $\mathrm{S}^{0}$ & $\mathrm{Cu}$ & $\mathrm{Pb}$ & $\mathrm{Zn}$ \\
\hline $1-1$ & Melnikovite & 0,02 to 0,36 & 70 & 45,2 & 36,48 & 34,5 & 0,31 & 0,33 & 0,20 & 0,02 \\
\hline $2-1$ & Pyrite & 0,03 to 0,86 & 80 & 44,12 & 24,89 & 42,99 & 0,095 & 0,53 & 0,14 & 0,30 \\
\hline \multirow{2}{*}{$3-1$} & Pyrite & \multirow{2}{*}{0,02 to 0,056} & 32 & \multirow{2}{*}{45,82} & \multirow{2}{*}{29,53} & \multirow{2}{*}{37,30} & \multirow{2}{*}{0,08} & \multirow{2}{*}{0,64} & \multirow{2}{*}{0,14} & \multirow{2}{*}{0,01} \\
\hline & Melnikovite & & 28 & & & & & & & \\
\hline $4-1$ & Chalcopyrite & 0,08 to 0,39 & 82 & 32,72 & 18,87 & 33,64 & 0,14 & 16,65 & 0,36 & 0,07 \\
\hline $5-1$ & Pyrrhotite & 0,02 to 0,32 & 93 & 63,74 & 56,10 & 36,31 & 0,74 & 0,28 & 0,22 & 0,01 \\
\hline
\end{tabular}




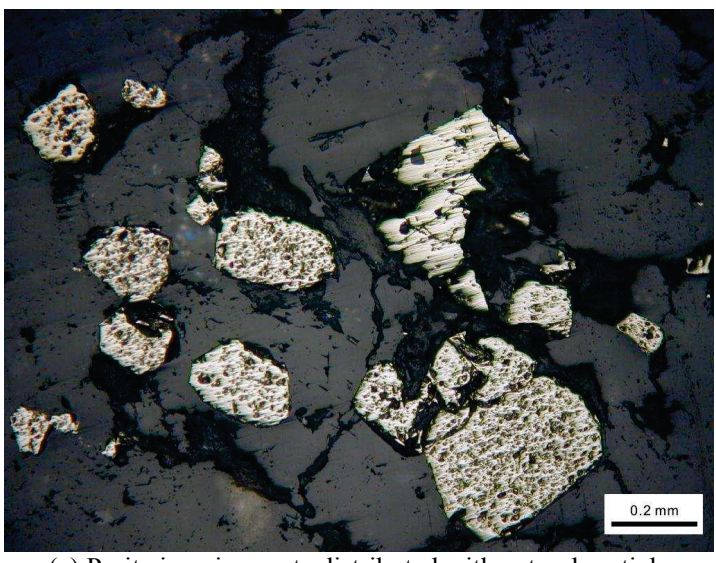

(a) Pyrite in vein quartz distributed with natural particle and replaced with sericite

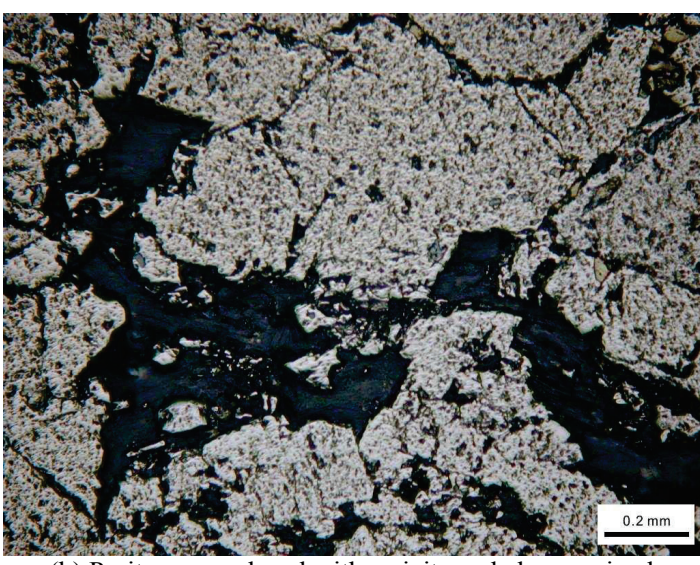

(b) Pyrite was replaced with sericite and close-grained chalcopyrite in its cranny

Figure 2 Typical photomicrographs of the samples

\subsection{Test series 1: on-site testing}

\subsubsection{Experimental site}

Ore stockpile blocks were examined, and the allowable sites for the experiments were selected at the level of $-180 \mathrm{~m}$ with the help of the miners. Three ore stockpiles were piled in several waste roadways, and the conditions of the ore stockpiles are described in Tab. 2.

Table 2 Description of the ore stockpiles at the level of $-180 \mathrm{~m}$

\begin{tabular}{|c|c|c|c|}
\hline No. of ore stockpiles & I & II & III \\
\hline Site & The center of $0^{\#}$ blind roadway & The south side of $6^{\#}$ blind roadway & The center of $6^{\#}$ blind roadway \\
\hline Ore type and content & $\begin{array}{c}\text { Middle crystal pyrite, } 80 \% ; \\
\text { small crystal pyrite, } 20 \%\end{array}$ & $\begin{array}{c}\text { Middle to small crystal pyrite, } 80 \\
\% \text {; large crystal pyrite, } 20 \%\end{array}$ & $\begin{array}{c}\text { Middle to small crystal pyrite, } 80 \% ; \\
\text { large crystal pyrite, } 20 \%\end{array}$ \\
\hline Shape, volume, and mass & Cone-shaped, $1,5 \mathrm{~m}^{3}, 6,2 \mathrm{t}$ & Half-pace-shaped, $2,1 \mathrm{~m}^{3}, 8,82 \mathrm{t}$ & Cone-shaped, $2,2 \mathrm{~m}^{3}, 9,24 \mathrm{t}$ \\
\hline $\begin{array}{c}\text { Environmental } \\
\text { conditions }\end{array}$ & $\begin{array}{c}\text { Damp floor, } 24{ }^{\circ} \mathrm{C} \text { to } 25^{\circ} \mathrm{C} ; \\
\text { humidity }>90 \%\end{array}$ & $\begin{array}{c}\text { Damp floor, } 24{ }^{\circ} \mathrm{C} \text { to } 26^{\circ} \mathrm{C} ; \\
\text { humidity }>90 \%\end{array}$ & $\begin{array}{c}\text { Floor with water, } 25^{\circ} \mathrm{C} \text { to } 27^{\circ} \mathrm{C} ; \\
\text { humidity }>90 \%\end{array}$ \\
\hline Air velocity & $0,02 \mathrm{~m} / \mathrm{s}$ & $0 \mathrm{~m} / \mathrm{s}$ & $0,05 \mathrm{~m} / \mathrm{s}$ \\
\hline
\end{tabular}

\subsubsection{Testing method and apparatus}

The testing method and apparatus used in the experiments are shown in Fig. 3. When piling the ore stockpile, three steel pipes $(25 \mathrm{~mm}$ in diameter and 1,500 $\mathrm{mm}$ in length; each having several small holes drilled on the wall) were placed in the ore stockpile vertically. For measuring temperatures in the ore stockpile, the temperature sensors were placed in these steel pipes and slowly moved up and down. The temperature gradient in the ore stockpile was read by the temperature logger. At the same time, a gas sample collector was placed in the steel pipe to measure $\mathrm{O}_{2}$ and $\mathrm{SO}_{2}$ concentrations. The environmental humidity and ore stockpile surface temperature were monitored by a hygrometer and an infrared thermal imager, respectively.

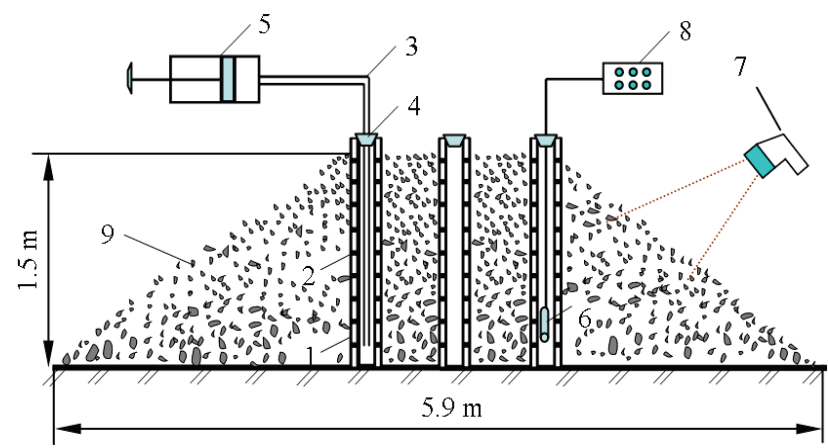

Figure 3 Schematic diagram of the on-site testing apparatus (1 - steel pipe; 2 - small holes drilled on the wall; 3 - rubber tube; 4 - rubber plug

5 - gas sample collector; 6 - temperature sensor; 7 - infrared thermal imager; 8 - temperature logger; 9 - mine ores)

\subsection{Test series 2: laboratory testing}

Some changes of the sulphide ore in the oxidization process and the characteristic indices corresponding to these changes can be determined by conducting test series 2. This part of the experiment was conducted in the laboratory to monitor the changes of the chemical composition, surface structure, and agglomeration of sulphide ores between the time before and after natural oxidization. The ore samples used for laboratory testing were the same as the ones used for on-site testing, and they were sieved into particles of size less than $200 \mu \mathrm{m}$. The environmental temperature of laboratory was maintained at $24{ }^{\circ} \mathrm{C}$ to $28{ }^{\circ} \mathrm{C}$ and humidity was held constant at $>90 \%$.

\section{Test results \\ 3.1 Result of test series 1}

The trend of the test results of temperature and $\mathrm{SO}_{2}$ and $\mathrm{O}_{2}$ concentrations in the ore stockpile and the environmental conditions of holes 1 and 2 are shown in Figs. 4(a) and 4(b), respectively. Given that hole 3 has been blocked, no measurement data were obtained.

\subsubsection{Temperature change}

Fig. 4 shows that the temperature change curves can be divided into three stages. In the first stage, the average temperature in the ore stockpile increased to $26^{\circ} \mathrm{C}$ to 27 ${ }^{\circ} \mathrm{C}$ after being stored for 16 days. The temperature 
increment was only $2{ }^{\circ} \mathrm{C}$ and the increase rate was 0,13 ${ }^{\circ} \mathrm{C} /$ day. In the second stage, the average temperature in the ore stockpile increased to $32{ }^{\circ} \mathrm{C}$ and $68{ }^{\circ} \mathrm{C}$ from 28 days to 43 days, and the increase rates were 0,22 and 0,98 ${ }^{\circ} \mathrm{C} /$ day, respectively. At 44 days, the temperature reached $87,25^{\circ} \mathrm{C}$ and the increase rate was $18{ }^{\circ} \mathrm{C} /$ day. In the third

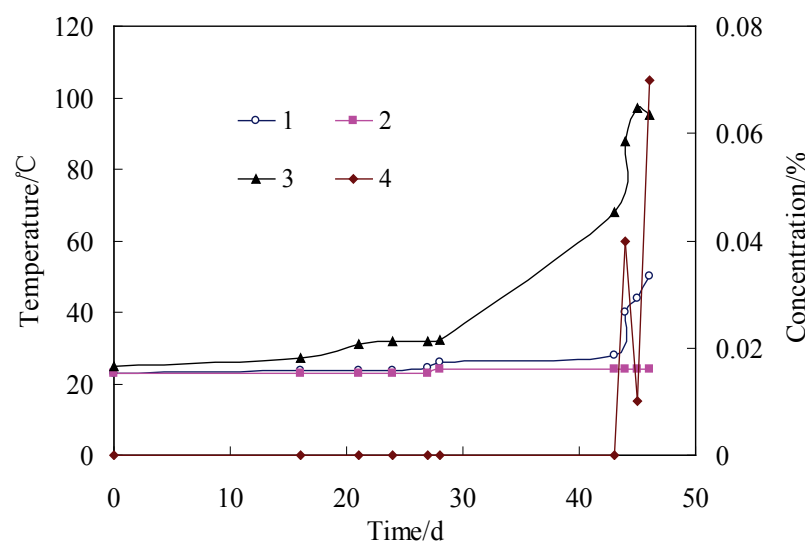

(a) Hole 1

Figure 4 Temperature and $\mathrm{SO}_{2}$ concentration curves (1 - Surface temperature of the sulfide ore stockpile; 2 - ambient temperature; 3 - temperature of the hole; 4 - $\mathrm{SO}_{2}$ concentration)

\subsection{2 $\mathrm{SO}_{2}$ release}

When the temperature in the ore stockpile was less than $60{ }^{\circ} \mathrm{C}$, almost no $\mathrm{SO}_{2}$ release was observed and the test results of $\mathrm{SO}_{2}$ concentration determined by the colorimetric gas detector trended to zero. However, when the temperature increased to $75^{\circ} \mathrm{C}$, a large amount of $\mathrm{SO}_{2}$ was released and the release rate increased significantly with the increase in temperature.

\subsection{3 $\mathrm{O}_{2}$ fluctuation}

In accordance with the test results, an interesting phenomenon was that $\mathrm{O}_{2}$ concentration in the ore stockpile was almost stable at $16 \%$ to $18 \%$, although the temperature in the ore stockpile was gradually increased. The diffusion ability of air in the ore stockpile likely increased with the increase in temperature because the thermal potential between the inside and outside of the ore stockpile increased.

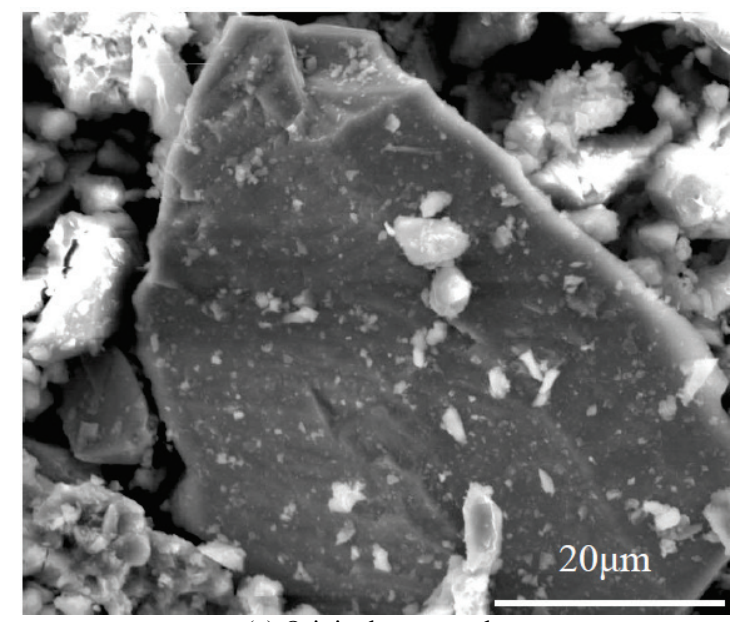

(a) Original ore sample stage, the temperature of the pile increased further to 97 ${ }^{\circ} \mathrm{C}$ after approximately 45 days and the increase rate was $10{ }^{\circ} \mathrm{C} /$ day. In the final stage, the temperature in the ore stockpile increased rapidly. Notably, when the temperature in the ore stockpile increased at 90 days, the ambient temperature was maintained at $26^{\circ} \mathrm{C}$ to $27^{\circ} \mathrm{C}$.

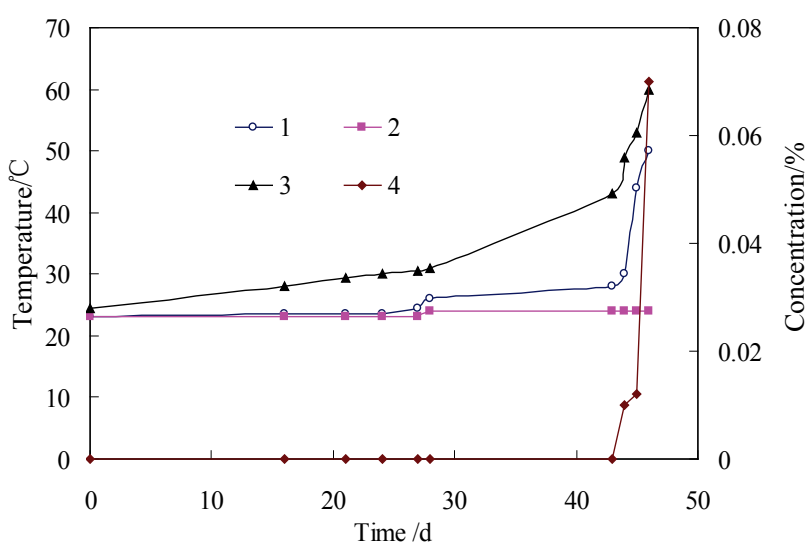

(b) Hole 2

\subsection{Result of test series 2 \\ 3.2.1 Structure change of sulphide ores}

We observed a significant change of the surface structure of oxidized sulphide ores compared with the original ore samples. A pale yellow powder-like substance was observed on the surface of the ore samples, which was actually generated by the oxidation of sulphide ores and elemental sulphur. The scanning electron microscope photographs of the original pyrite ore samples and oxidized pyrite ores are shown in Figs. 5(a) and 5(b), respectively.

Fig. 5 shows that the original sample was angular and its surface was smooth, whereas the sample oxidized for approximately 40 days was loose and broken because of oxidation in the laboratory environment. Changes of the surface structure were likely due to the oxidation behaviour of sulphide ores.

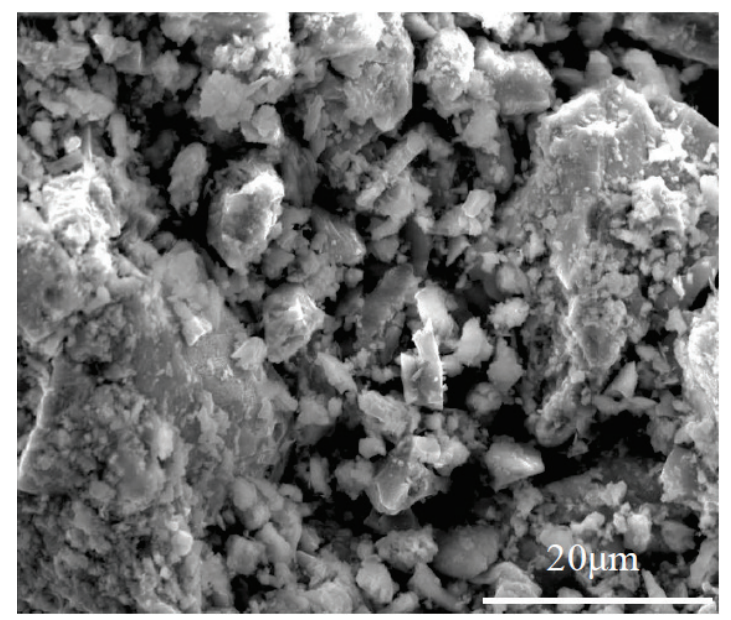

(b) Ore sample oxidized for 40 days

Figure 5 SEM photographs of pyrite 


\subsubsection{Concentration changes of water-soluble ferrous ions and sulfate ions}

Currently, the determination of water-soluble iron sulfide ore $\left(\mathrm{Fe}^{2+}+\mathrm{Fe}^{3+}\right)$ and sulfate ion $\left(\mathrm{SO}_{4}{ }^{2-}\right)$ contents and $\mathrm{pH}$ value has become one of the means to analyze the spontaneous combustion tendency. A larger ion content

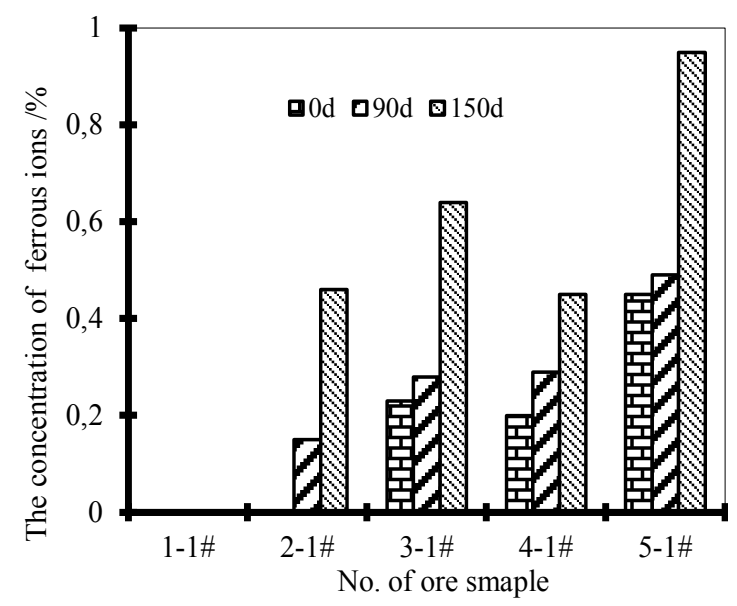

Figure 6 (a) The concentration changes of water-soluble ferrous ions

The results showed that the contents of the watersoluble iron sulfide ore $\left(\mathrm{Fe}^{2+}+\mathrm{Fe}^{3+}\right)$ and sulfate ion $\left(\mathrm{SO}_{4}{ }^{2-}\right)$ gradually increased with the increment of oxidation time. In ore samples 2-1 and 3-1, the content of sulfate ions was increased by approximately $3 \%$. In ore sample 4-2, the content of sulfate ions was increased from $2,70 \%$ to $4,44 \%$. Thus, the change state of the oxidized sulfide ore can be determined by measuring the contents of water-soluble iron sulfide ore $\left(\mathrm{Fe}^{2+}+\mathrm{Fe}^{3+}\right)$ and sulfate ion $\left(\mathrm{SO}_{4}{ }^{2-}\right)$ of the oxidation product at a low temperature.

\subsubsection{Agglomeration of sulphide ores}

Sulfur, which was produced in the process of oxidation of the sulfide ore, had a strong cementing effect

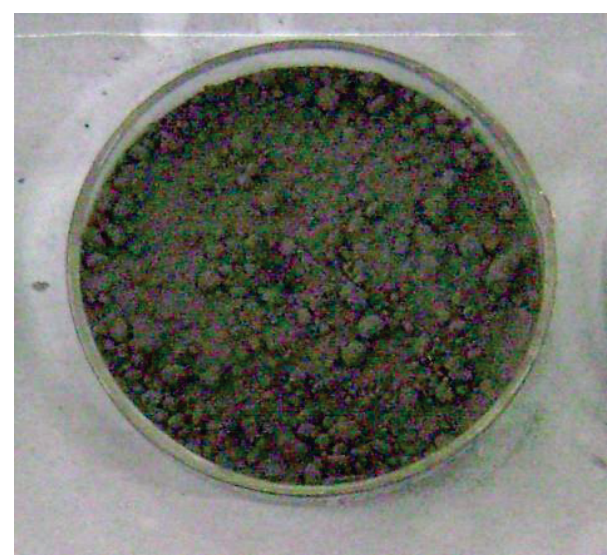

(a) Agglomeration of some small particles Figure 7 Agglomeration photos of samples in the laboratory change corresponds to a faster oxidation of sulfide ores in unit time. Figs. 6(a) and 6(b) show the change of watersoluble iron sulfide ore $\left(\mathrm{Fe}^{2+}+\mathrm{Fe}^{3+}\right)$ and sulfate ion $\left(\mathrm{SO}_{4}{ }^{2-}\right)$ contents of the original sulfide ore versus the samples oxidized for 90 and 150 days.

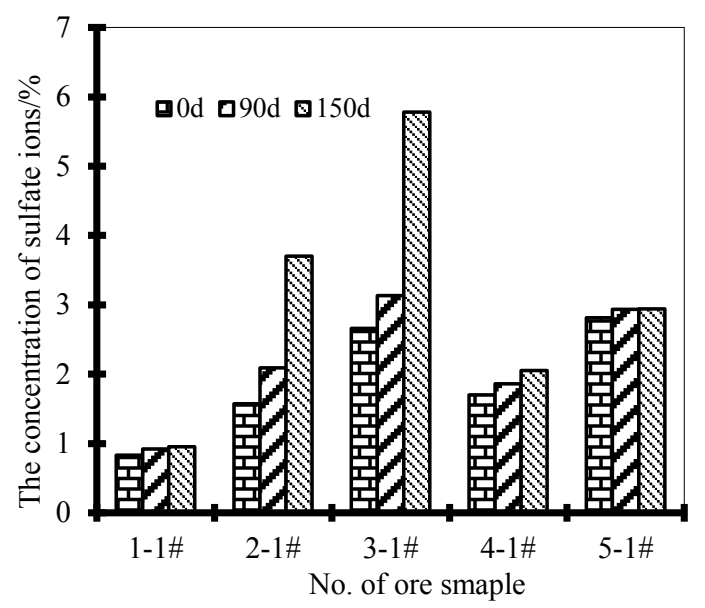

Figure 6 (b) The concentration changes of sulfate ions

on the sulfide ore, which led to difficulties of ore removal in the stope. Crushed ore powder samples were placed in the laboratory with humid environmental conditions for a certain period of time. Some ore particles were observed to have bonded together (Fig. 7). The agglomeration of sulfide ores was due to cementation of sulfur. A more severe agglomeration leads to a larger amount of sulfur. When the temperature of sulfur reached its ignition point, spontaneous combustion of sulfide ores would be easily triggered under the condition of heat accumulation. Therefore, the agglomeration of sulfide ores could be used as a precursor to the spontaneous combustion of sulfide ores.

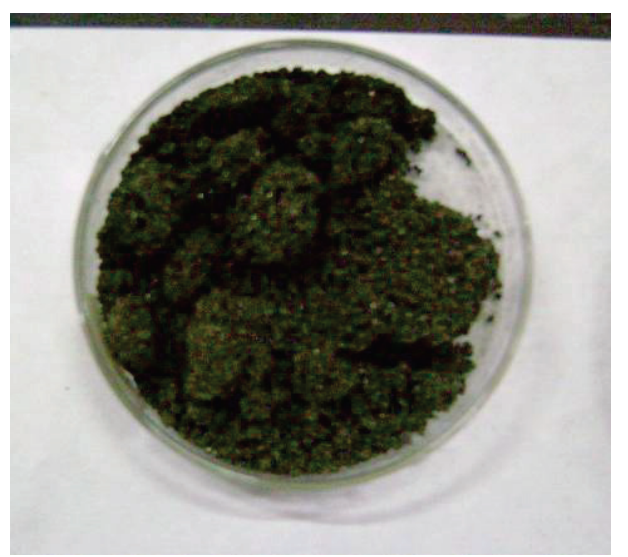

(b) Serious agglomeration

structure change, agglomeration of sulfide ores, and concentration changes of water-soluble ferrous ions and sulfate ions, could reflect the oxidation characteristics of sulfide ores. However, in fact, the aforementioned
According to the results of test series 1 and 2, five indices, namely, temperature change, $\mathrm{SO}_{2}$ release, 
phenomena were the result of deep oxidation or spontaneous combustion of sulfide ores, except for temperature change.

Surface temperature change on sulfide ore stockpiles could indirectly reflect the nature of oxidation of sulfide ores to some extent, and temperature change was closely related to the various stages of spontaneous combustion. Figs. 4(a) and 4(b) show that the temperature curve changes run through the entire process of spontaneous combustion from oxidation to fire. The same trend of temperature changes was observed at the stockpile surface and its interior. As such, temperature is a suitable indicator for monitoring the spontaneous combustion of sulfide ore stockpiles at the early stage. However, little attention has been focused on the processes causing temperature anomalies on the surface, which play a dominant role in the process of preventing spontaneous combustion. Temperature anomalies analysis is one of the most complex subjects in the detection of fire source.

\section{Detection method}

Based on the detection method of Liu [4], the emergence and development of self-ignition of sulfide ores are extremely complex physical and chemical processes.

\subsection{Theoretical analysis and model \\ 4.1.1 Thermal equilibrium of the sulphide ore stockpile}

As mentioned previously, spontaneous combustion of sulfide ores is the result of extremely complex physical and chemical processes. The site, duration, and extent of spontaneous combustion varied extensively, but still followed the heat balance equation. Based on heat balance theory, heat transfer between spontaneous combustion sites is satisfied by the following two conditions:

(1) The heat output from the inside to the outside of the ore stockpile is equal to that from the surface to the air.

(2) Heat production in the ore stockpile is equal to the heat output from inside to outside.

\subsubsection{Partial differential equation of heat conduction}

For reasons of simplicity, we have the following assumptions:

(1) The ore stockpile surrounding the fire source is homogeneous and isotropic.

(2) The area of the fire source is small and the distance from the fire source to the ore stockpile surface is longer than the size of the fire source, which can be considered the point fire source.

(3) Heat convection inside the ore stockpile is ignored.

The one-dimensional temperature distribution in the ore stockpile along the vertical central axis of the fire source can be described by Eq. (1):

$\rho c \frac{\partial T}{\partial t}=\lambda \nabla^{2} T+q_{v}$ where $\rho$ is the apparent density of sulfide ores in $\mathrm{kg} / \mathrm{m}^{3}, c$ is the apparent heat capacity of sulfide ores in $\mathrm{J} /(\mathrm{kg} \cdot \mathrm{K}), T$ is the temperature field function, $\lambda$ is the effective thermal conductivity in $\mathrm{W} /(\mathrm{m} \cdot \mathrm{K}), \nabla^{2}$ is Laplacian, and $q_{v}$ is the inner fire source in $\mathrm{W}$.

In steady state, Eq. (1) can be rewritten as Eq. (2):

$\lambda \nabla^{2} T+q_{v}=0$

The fire source was considered the point heat source. The inner heat source term can be written as $q \cdot \delta(r)$. As such, the heat exchange equation of the point heat source in steady state can be defined as follows:

$\nabla^{2} T=-\frac{1}{\lambda} q \cdot \delta(r)$

where $q$ is the heat source intensity and $\delta(r)$ is the $\delta$ function, which indicates an infinite heat source at $r=0$ and no source at $r \neq 0$.

In the sphere coordinate system, Eq. (3) can be written as follows:

$\nabla^{2} T=\frac{1}{r^{2}} \cdot \frac{\mathrm{d}}{\mathrm{d} r}\left(r^{2} \cdot \frac{\mathrm{d} T}{\mathrm{~d} r}\right)=-\frac{q}{\lambda} \cdot \delta(r)$

Based on Gauss' law:

$$
\begin{aligned}
& \iiint_{\Omega} \nabla^{2} T \mathrm{~d} v_{\varepsilon}=\iiint_{\Omega} \nabla^{2} T \mathrm{~d} x \mathrm{~d} y \mathrm{~d} z= \\
& =\oiint_{\Sigma} \nabla T \mathrm{~d} S=\oiint_{\Sigma} \frac{C_{1}}{r^{2}} \mathrm{~d} S=\iiint_{\Omega}-\frac{q}{\lambda} \delta(r) \mathrm{d} v_{\varepsilon} \\
& \lim _{\varepsilon \rightarrow 0} \oiint_{\Sigma} \frac{C_{1}}{r^{2}} \mathrm{~d} S=\frac{C_{1}}{r^{2}} \cdot 4 \pi \varepsilon^{2}=-\frac{q}{\lambda}
\end{aligned}
$$

where $C_{1}$ is a constant and the following equation can be obtained:

$$
C_{1}=-\frac{q}{4 \pi \lambda}
$$

Substituting the value of $C_{1}$ into Eq. (6), the surface temperature can be described as follows:

$T=\frac{q}{4 \pi \lambda r}$

where $r$ denotes the distance between the fire source and an arbitrary point on the ore stockpile surface.

Generally, a thermograph detects the differences in infrared radiation intensity emitted from the surface of an object. The differences are caused by the different heat contents of the object or its various parts and are influenced by the surface emissivity characteristics. When a nonhomogeneous structure, with different thermal characteristics and initial thermal equilibrium with its surrounding, is exposed to heat stimulation, temperature differences occur in the structure and its visible surfaces. 
The surface temperature distribution $T(x)$ can be established as follows:

$$
T(x)=\frac{q}{4 \pi \lambda r}+T_{a}=\frac{q}{4 \pi \lambda r \cdot \sqrt{h^{2}+x^{2}}}+T_{a}
$$

where $T_{a}$ is the ambient temperature in ${ }^{\circ} \mathrm{C}$. The highest temperature differences on the ore stockpile surface can be described as follows:

$$
\Delta T_{\max }=\frac{q}{4 \pi \lambda h}-\frac{q}{4 \pi \lambda \cdot \sqrt{h^{2}+x^{2}}}
$$

Eqs. (8) to (10) show that the depth and intensity of the fire source were unknown. In recent years, infrared thermal imagers have been successfully applied to a diverse range of subjects, including the detection of inner heat source in thermal texture maps, civil engineering, and assessing landfill sites [17, 18]. As such, the surface temperature could be measured by an infrared detector and temperature differences in the stockpile could be calculated. The value of $x$ can also be obtained by in situ measurement. For this reason, obtaining information on the inner fire source, including depth and intensity, is possible.

\subsubsection{Surface temperature difference identification of ore stockpile}

Based on the detection level of the IRI-1011 infrared thermal imager, the detection zone was determined. The simulation range is shown in Tab. 3.

When the internal temperature of the stockpile was greater than $60{ }^{\circ} \mathrm{C}$, the ore was close to the self-ignition duration [4]. As such, based on the mine underground condition, $T_{0}=27{ }^{\circ} \mathrm{C}$ was considered the ambient temperature. In addition, the coefficient of the heat conductivity of sulfide ores was determined to be $\lambda=0,84$ $\mathrm{W} /\left(\mathrm{m} \cdot{ }^{\circ} \mathrm{C}\right)$ by simulating thermal transfer under the condition of different $h$ values from $1 \mathrm{~m}$ to $5 \mathrm{~m}$ at temperatures of 60 and $100{ }^{\circ} \mathrm{C}$. The relationship between detection depth and detection zone in different heat source temperatures is required in numerical simulation. The

\begin{tabular}{|c|c|c|c|c|c|}
\hline Distance of measurement $/ \mathrm{m}$ & 1 & 2 & 3 & 4 & 5 \\
\hline Field of view $/(\mathrm{m} \times \mathrm{m})$ & $0,35 \times 0,35$ & $0,71 \times 0,71$ & $1,06 \times 1,06$ & $1,41 \times 1,41$ & $1,76 \times 1,76$ \\
\hline
\end{tabular}
results are shown in detail in Tab, 4.

\begin{tabular}{|c|c|c|c|c|c|c|}
\hline \multirow{3}{*}{ Detection depth / m } & \multicolumn{6}{|c|}{ Detection zone $/(\mathrm{m} \times \mathrm{m})$} \\
\hline & \multicolumn{3}{|c|}{ Heat source temperature of $60^{\circ} \mathrm{C}$} & \multicolumn{3}{|c|}{ Heat source temperature of $100^{\circ} \mathrm{C}$} \\
\hline & $2 \times 2$ & $1,5 \times 1,5$ & $1 \times 1$ & $2 \times 2$ & $1,5 \times 1,5$ & $1 \times 1$ \\
\hline 1 & 5,25 & 4,23 & 2,78 & 10,5 & 8,46 & 5,57 \\
\hline 2 & 1,39 & 0,95 & 0,5 & 2,78 & 1,9 & 1,0 \\
\hline 3 & 0,53 & 0,33 & 0,16 & 1,06 & 0,67 & 0,33 \\
\hline 4 & 0,25 & 0,15 & 0,07 & 0,5 & 0,3 & 0,14 \\
\hline 5 & 0,14 & 0,08 & 0,04 & 0,27 & 0,16 & 0,07 \\
\hline
\end{tabular}

Table 4 Relationship between detection depth and detection zone in different heat source temperatures $\left(60\right.$ and $\left.100{ }^{\circ} \mathrm{C}\right)$

Tab. 4 shows that, close to the self-ignition duration and at a detection depth of $1 \mathrm{~m}$, the maximum temperature difference was $2,78^{\circ} \mathrm{C}$ at a scope of $1 \times 1 \mathrm{~m}$. Under the same condition, the maximum temperature differences were 4,23 and $5,25{ }^{\circ} \mathrm{C}$ at the scopes of $1,5 \times$ $1,5 \mathrm{~m}$ and $2 \times 2 \mathrm{~m}$, respectively. Evidently, spontaneous ignition ores resulted in temperature differences on the surface from the center to the surrounding. The larger the detection zone, the larger the temperature difference. Therefore, the effects of utilizing thermal imaging equipment are improved by enlarging the light-sensing area. However, limited by the total field of view and the field condition, the light-sensing area will not be so ideal. For the IRI-1011 infrared thermal imager detection system, the light-sensing area is approximately $1 \times 1 \mathrm{~m}$ when the detection distance is approximately equal to 3 $\mathrm{m}$, whereas the light-sending area is smaller than $2 \times 2 \mathrm{~m}$ at a detection distance of $5 \mathrm{~m}$. As a result, the temperature differences obtained in the scope of $1 \times 1 \mathrm{~m}$ are smaller when the position of the fire source is deeper.

Considering that the ore stockpile has a large volume containing a thermal source that maintains a constant temperature at a certain period of time and is covered by ores, some information on the fire source will be provided as the feedback to its surface when the ore stockpile with spontaneous combustion tendency emits infrared radiation. The infrared thermal imager of the fire detection technology could scan the ore stockpile surface temperature field distribution and obtain the ore stockpile temperature field information based on the anomalies of surface temperature distribution. As such, we identify whether a fire has been ignited within the ore stockpile and its depth.

\subsection{Fire source location}

As mentioned previously, the heat transfer performance of the fire source is generated by the balance of the three-dimensional temperature field within the ore stockpile. A specific description of the location of the fire source is shown in Fig. 8.

We designated the fire source as central point $O$ and the vertical distance from point $O$ to the surface of the ore stockpile as $h$. Based on the projection theorem, the projection of $O$ on the ore stockpile surface is $O^{\prime}$. Moreover, $A$ is considered an arbitrary point on its surface. The following equation can be obtained based on the right triangle theorem:

$$
r=\sqrt{h^{2}+x^{2}}
$$




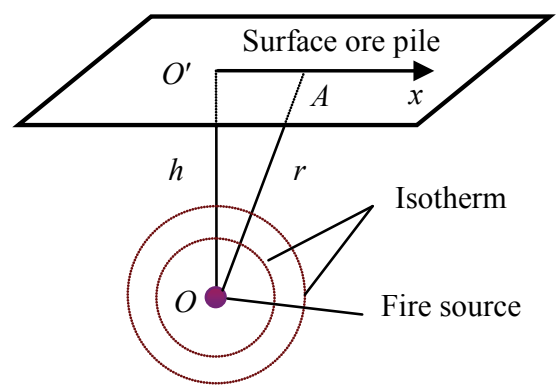

Figure 8 Schematic of the location of the fire source of spontaneous ignition

\subsection{Field practice}

In our investigation, the IRI-1011 infrared thermal imager was used to measure the surface temperature of the sulfide ore stockpile in the stope of a pyrite mine in Henan Province, of which spontaneous combustion occurred. The environment of the stope with sulfide ore stockpiles was severe, with temperatures of $30{ }^{\circ} \mathrm{C}$ to 40 ${ }^{\circ} \mathrm{C}, \mathrm{SO}_{2}$, and humidities of $90 \%$ to $100 \%$. Given that the surface of ore stockpiles is coarse, radiation reflected on the surface will be reflected many times. The correct measurement data of surface temperature on the ore stockpile are slightly difficult to obtain until a steady state is reached because each reflection could absorb parts of radiation energy. Considering the aforementioned conditions, we determined the surface emissivity of the ores by conducting experiments $(\varepsilon=0,88)$. The typical pictures of the surface temperature on the ore stockpile measured by the thermal imager are shown in Fig. 9.

The measured temperature data were close to the practical situation. Based on the method of fire source location, the highest temperature point $O^{\prime}$ could be determined using the infrared thermal imager. Then, point $A$ is combined with point $O^{\prime}$ to estimate the depth of the fire source. In addition, the thermal imager shows that the temperatures of point $O^{\prime}$ and point $A$ are $39^{\circ} \mathrm{C}$ and 38,3 ${ }^{\circ} \mathrm{C}$, respectively, and the distance between these two points is $0,48 \mathrm{~m}$. By calculation and comprehensive analysis, the fire source could be estimated. Field test of grouting through point $A$ proves that the result of detection corresponded with the practical situation.

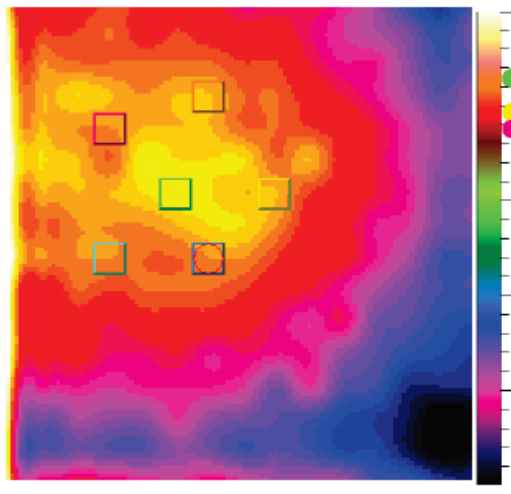

(a) Infrared image of the ore stockpile

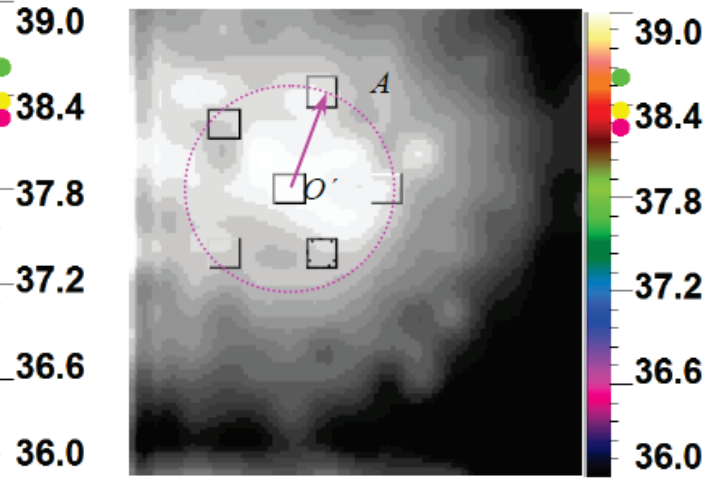

(b) infrared grayscale image of the ore stockpile.

Figure 9 Thermal image of the surface of the ore stockpile of a pyrite mine.

\section{Conclusion}

Two parts of the experiments were conducted in the allowable sites of a mine and the laboratory to assess the oxidation characteristics of sulfide ores, and the temperature anomaly analyses on surface temperature of sulfide ore stockpiles were investigated. The investigation led to the following conclusions:

(1) The experimental results show that surface temperature change, $\mathrm{SO}_{2}$ release, structure change, agglomeration of sulfide ores, and concentration changes of water-soluble ferrous ions and sulfate ions were five typical characteristics in the oxidation and spontaneous combustion processes of sulfide ores in a stockpile with environmental temperatures of $24^{\circ} \mathrm{C}$ to $28^{\circ} \mathrm{C}$.

(2) As an important index, surface temperature change on sulfide ore stockpiles was closely related to the three various stages of spontaneous combustion, which could indirectly reflect the nature of oxidation of sulfide ores and detect the inner fire source at the early stage.

(3) The surface temperatures of sulfide ore stockpiles were also measured by the IRI-1011 infrared thermal imager. Combined with the partial differential equation of heat conduction, a detection method of spontaneous combustion disaster of sulfide ore stockpiles on the basis of infrared thermal imaging was proposed. The field test results of the pyrite mine of Henan Province showed that the fire source could be estimated and a fairly good agreement between the detection result and the practical situation was observed.

\section{Acknowledgement}

This work was supported in part by NSFC under Grant Nos. 51104134 and 51304179, Zhejiang Provincial Natural Science Foundation of China under Grant No. LY14E040001, Program of General Administration of Quality Supervision, Inspection and Quarantine of China under Grant No. 2011QK390, and Program of Safety Production Science and Technology of Zhejiang Provincial under Grant No. 2013A1011.

\section{References}

[1] Somot, S.; Finch, J. A. Possible role of hydrogen sulphide gas in self-heating of pyrrhotite-rich materials. // Minerals Engineering. 23, 2(2010), pp. 104-110. DOI: 10.1016/j.mineng.2009.10.011

[2] Good, B. H. The oxidation of sulphide minerals in the Sullivan Mine. // CIM Bulletin. 70, 782(1977), pp. 83-88. 
[3] Brown, R. L.; Miller, F. J. L. Pollution problems associated with Sullivan Mine hot muck. // CIM Bulletin. 70, 782(1977), pp. 89-92.

[4] Liu, H.; Wu, C.; Shi, Y. Locating method of fire source for spontaneous combustion of sulfide ores. // Journal of Central South University. 18, 4(2011), pp. 1034-1040. DOI: 10.1007/s11771-011-0800-9

[5] Huang, Y. J. Spontaneous combustion of millions of tons of ores at an ore field in Guizhou Province. China Firefighting Online. 2009. http://119.china.com.cn/mhqx/txt/200904/17/content 2855795.htm. (06.11.2012).

[6] Xu, J. Spontaneous combustion of 30 tons of iron ore stockpiles at an outdoor yard. China Firefighting Online. 2009. http://119.china.com.cn/mhqx/txt/2009-03/10/content 2782888.htm (06.11.2012).

[7] Boon, M. The mechanism of 'direct' and 'indirect' bacterial oxidation of sulphide minerals. // Hydrometallurgy. 62, 1(2001), pp. 67-70. DOI: 10.1016/S0304-386X(01)00182-7

[8] Yang, F. Q.; Wu, C.; Li, Z. J. Investigation of the propensity of sulfide concentrates to spontaneous combustion in storage. // Journal of Loss Prevention in the Process Industries. 24, 2(2011), pp. 131-137. DOI: 10.1016/j.jp.2010.11.006

[9] Yang, F. Q.; Wu, C. Mechanism of mechanical activation for spontaneous combustion of sulfide minerals. // Transactions of Nonferrous Metals Society of China. 23, 1(2013), pp. 276-282. DOI: 10.1016/S1003-6326(13)62457-7

[10] Dunn, J. G. The oxidation of sulphide minerals. // Thermochimica Acta. 300, 1(1997), pp. 127-139. DOI: 10.1016/S0040-6031(96)03132-2

[11] Iliyas, A.; Hawboldt, K.; Khan, F. Kinetics and safety analysis of sulfide mineral self-heating. // Journal of Thermal Analysis and Calorimetry. 106, 1(2011), pp. 53-61. DOI: 10.1007/s10973-011-1621-7

[12] Bouffard, S. C.; Senior, G. D. A new method for testing the self-heating character of sulphide concentrates. // Minerals Engineering. 24, 12(2011), pp. 1517-1519. DOI: 10.1016/j.mineng.2011.07.012

[13] Chen, Y. W.; Li, Y. R.; Cai, M. F.; Belzilem, N.; Dang, Z. Preventing oxidation of iron sulfide minerals by polyethylene polyamines. // Minerals Engineering. 19, 1(2006), pp. 19-27. DOI: 10.1016/j.mineng.2005.04.007

[14] Barnabe, N.; Edwin, J. S.; Finch, J. A. Estimating activation energy from a sulfide self-heating test. // Minerals Engineering. 24, 15(2011), pp. 1645-1650. DOl: 10.1016/j.mineng.2011.08.019

[15] Hogland, W.; Marques, M. Physical, biological and chemical processes during storage and spontaneous combustion of waste fuel. // Resources, Conservation and Recycling. 40, 1(2003), pp. 53-69. DOI: 10.1016/S09213449(03)00025-9

[16] Kim, A. G. Locating fires in abandoned underground coal mines. // International Journal of Coal Geology. 59, 2(2004), pp. 49-62. DOI: 10.1016/j.coal.2003.11.003

[17] Zhang, J. Z.; Kuenzer, C. Thermal surface characteristics of coal fires 1: results of insitu measurements. // Journal of Applied Geophysics. 63, 3(2007), pp. 117-134. DOI: 10.1016/j.jappgeo.2007.08.002

[18] Singh, A. K.; Singh, R. V. K.; Singh, M. P.; Chandra, H.; Shuka, N. K. Mine fire gas indices and their application to Indian underground coal mine fires. // International Journal of Coal Geology. 69, 3(2007), pp. 192-204. DOI: 10.1016/j.coal.2006.04.004

[19] Xie, J.; Xue, S.; Cheng, W. M.; Wang, G. Early detection of spontaneous combustion of coal in underground coal mines with development of an ethylene enriching system. // International Journal of Coal Geology. 85, 1(2011), pp. 123-127. DOI: 10.1016/j.coal.2010.10.007

[20] Agarwal, R.; Singh, D.; Chauhan, D. S.; Singh, K. P. Detection of coal mine fires in the Jharia coal field using
NOAA/AVHRR data. // Journal of Geophysics and Engineering. 3, 3(2006), pp. 212-218. DOI: 10.1088/1742$2132 / 3 / 3 / 002$

[21] Wessling, S.; Kessels, W.; Schmidt, M.; Krause, U. Investigating dynamic underground coal fires by means of numerical simulation. // Geophysical Journal International. 172, 1(2008), pp. 439-454. DOI: 10.1111/j.1365246X.2007.03568.x

[22] Xue, S.; Dickson, B.; Wu, J. Application of ${ }^{222}$ Rn technique to locate subsurface coal heatings in Australian coal mines. // International Journal of Coal Geology. 74, 2(2008), pp. 139-144. DOI: 10.1016/j.coal.2007.11.005

[23] Wang, Z. P.; Cheng, W. M.; Xin, S.; Song, X. M.; Su, S. G. The calculation of close-range coal inflammation position at coal-roads based on infrared detecting and inverse heat conduction technology. // Journal of China Coal Society. 28 , 6(2003), pp. 603-607.

\section{Authors' addresses}

Hui Liu, Ph.D., Associate Professor (Corresponding author) College of Quality \& Safety Engineering, China Jiliang University, Room 428, Yang Bei Building, No. 258, Xueyuan Street, Higher Education zone of Xiasha, Hangzhou City, 310018, Zhejiang Province, P. R. China E-mail: liuhui2003@126.com

\section{Zhixing Wang, M.S.}

College of Quality \& Safety Engineering, China Jiliang University, Room 301, Yangzhong Building, No. 258, Xueyuan Street, Higher Education zone of Xiasha, Hangzhou City, 310018, Zhejiang Province, P. R. China.

E-mail: wangzhixing211@126.com

\section{Jian Zhong, Ph.D.}

School of Geography, Earth and Environmental Sciences, University of Birmingham, Birmingham, B15 2TT, United Kingdom

E-mail: zxj160@bham.ac.uk

\section{Zhengwen Xie, Ph.D., Associate Professor}

College of Quality \& Safety Engineering, China Jiliang University, Room 428, Yang Bei Building, No.258, Xueyuan Street, Higher Education zone of Xiasha, Hangzhou City, 310018, Zhejiang Province, P. R. China E-mail: xiezhengwen@126.com 